\title{
Effect of cereals milling on the contents of phytic acid and digestibility of minerals and protein
}

\section{Müge Hendek Ertop1, Müberra Bektaş², Rabia Atasoy ${ }^{1}$}

\author{
1 - Kastamonu University, Kastamonu, Turkey \\ 2 - Gümüşhane University, Gümüşhane, Turkey
}

Keywords:
Cereal
Debranning
Mineral content
Phytic acid
Milling
Bioavailability

Article history:

Received

21.07.2019

Received in revised form 08.12.2019

Accepted

30.03.2020

Corresponding author:

Müge Hendek Ertop

E-mail:

mugeertop@

kastamonu.edu.tr

DOI:

$10.24263 / 2304-$

974X-2020-9-1-12

\section{Abstract}

Introduction. The aim of the study was to the examination of effects of the milling process which were applied differently to cereals for commercially flour production, on the phytic acid, microelement, and in-vitro digestibility.

Materials and methods. The nutritional consequences of the milling processes of the cereals (wheat, barley, rye, oat, paddy) were evaluated by examining protein, ash, phytic acid, mineral contents, and protein/mineral digestibility rates. Mineral contents were measured by inductively coupled plasma optical emission spectroscopy (ICP-OES), protein content by Kjeldahl method, and mineral digestibility and phytic acid were determined by in-vitro assays.

Results and discussion. The dehulling/debranning process increased the protein digestibility rate over to $65 \%$ and decreased phytic acid content significantly $(p<0.05)$ of the cereal grains except for rye. The mineral digestibility raised for all grain samples, but it was evaluated statistically insignificant $(p>0.05)$. The rice flour was the sample that had the lowest phytic acid content $(921.87 \mathrm{mg} / 100 \mathrm{~g})$ and the highest mineral digestibility rate $(58.35 \%)$. Although the contents of total ash and some of the minerals ( $\mathrm{Na}, \mathrm{Ca}, \mathrm{K}, \mathrm{Mg}, \mathrm{Zn}, \mathrm{Fe}, \mathrm{Ba}$, and $\mathrm{P}$ ) decreased in flours especially in wheat and paddy, the rate of some minerals ( $\mathrm{Na}, \mathrm{Mg}, \mathrm{Zn}, \mathrm{Fe}$, and $\mathrm{Al}$ ) increased due to their distribution and localization in the grain layers, especially in rye and oat. The result of the study has shown that the level of the minerals changed depending on the bran/hull content of the grains, and the milling process was more effective on phytic acid content and on protein digestibility than on the mineral digestibility. While the phytic acid content was located on the outer layer of the grain, it was decreased in the kernel.

Conclusions. Although the phytic acid content which affects the digestibility of the cereals were reduced by the milling process, the combination of different treatments such as soaking, fermentation could be suggested for improving the nutritional quality of the cereal. 


\section{Introduction}

Cereals have been the staple foods in many countries and they are the main carbohydrate and energy sources in the human diet. They are also a major source of proteins, minerals, dietary fiber and some micronutrients which are located in the grain fractions at different rates [1]. The main fractions of the wheat grain and other cereals are endosperm, bran and germ. Moreover, the barley, oat and rye have a hull layer which has a high level of ash content. The endosperm consists of starch granules embedded in a protein matrix. A large part of the storage proteins in cereals, especially in rye and oats, are found in the endosperm. The part called bran which is found at the rate of $14-16 \%$ in the grains, consists of pericarp, testa, hyaline and aleurone layers. Aleurone layer, which is located just above the endosperm and constitutes an important part of the bran layer, is very rich especially in terms of mineral content such as $\mathrm{K}, \mathrm{Mg}, \mathrm{Ca}, \mathrm{P}, \mathrm{Na}, \mathrm{Al}, \mathrm{Fe}$ and $\mathrm{Zn}[2,3]$. The different minerals distribute in different layers across the grain. This change come together with the factors of debranning and milling process, it may be seen an increase or decrease in various minerals after milling [4]. For example, in the milling process of the wheat, the aleurone layer which rich in mineral contents is usually removed along with the other external layers from the endosperm, and a flour which has lower mineral content than whole grain flour is obtained [5]. The rate of the ash in the different fractions with respect to grain variety changes like as the minerals, and the rate increases from the inner towards external layers [6]. Therefore, the dehulling/debranning process make the ash content of the grain decrease, and the rate of ash $(\%)$ is accepted as an indicator which is exhibited the separation efficiency of the bran from the endosperm [7].

Since their better technological and sensory properties, the refined cereals may be preferred more than whole grain or bran-enriched products. However, the growing interest to natural, functional and minimally processed foods is influencing the preference of customers in recent years. Especially the cereal grains which taken an important part of the daily diet have the potential usage in the production of enriched functional foods [8]. On the other hand, the antinutrients which are another aspect of the outer fraction of the cereals may be seen as a negative factor for daily diet. For instance, the bran layer is much richer in minerals than endosperm. However, its minerals have low digestibility. Because the minerals located in bran are physically entrapped in strong cell wall structures and they also occur as phytate form in bran and germ [4]. Therefore, the fractions of the cereal grains should be evaluated separately with respect to the advantage of nutritional components and disadvantage of antinutrients. Because, while the nutrient compounds such as mineral and protein located in different layers in the grain and their location and rates changed according to cereal types, the level and distribution of antinutrients such as phytic acid also affect from same factors. In several studies were reported that the bran layer of the several kinds of cereal such as wheat and rice contains a high amount of phytic acid which acts as an antinutrient substance $[9,10]$. The phytic acid which is the main antinutrient compound found in cereals reduces mineral bioavailability and protein absorption of them thanks to its chelating properties. It causes micronutrient malnutrition and mineral deficiencies which are a widespread global health problem in many countries. Dehulling/debranning methods as well as other pretreatment and processing techniques as soaking, fermentation, germination, can reduce the phytic acid which is especially located in the outer layer of the cereals. [11].

The debranning/dehulling process is the pre-milling stage which is removed the external layers (hull and/or bran) along with the aleurone layer of the kernel [6] in modern mills. Moreover, allowing to obtain endosperm layer that is produced refined flour. However, the level of the bioactive compounds, such as fiber and phenolic compounds and minerals 
deployed in the outer layer may decrease [8]. On the other hand, the whole grain of some cereals such as rye and barley is ground in the stone mills commercially, and then the bran/hull particles are separated from the flour. Even if optimum conditions are provided, a little amount of bran may mingle to the flour in the milling process. This situation affects the ash content and the composition of the minerals of the flours [12].

The aim of the study was to evaluate the relationship between the nutritional content of some grains (wheat, barley, rye, oats, and paddy (whole rice)) and the debranning/dehulling treatment which was the main stage of the milling process. The effects of these treatments were examined by ash, protein and mineral content as well as indirect methods such as mineral and protein digestibility. The data obtained before and after the milling process were evaluated statistically.

\section{Materials and methods}

\section{Materials}

In this study, the wheat sample named as "Ekiz wheat" (Triticum aestivum), were supplied from the grains which harvested in July 2017 at Devrekani, Kastamonu (Turkey). It was milled in a modern milling factory (Üçbaşak Milling, Devrekani, Kastamonu) to produce flour. Before milling, the wheat grains were cleaned (by used differences in size, shape, color, specific weight and magnetic force to separate foreign material from the grains). The kernels were first hydrated for tempering (app. 2\%), ground, sifted and separated (milling yield 70\%). The wheat flour was sifted by 212-micron sieve because of that min $98 \%$ of it must pass from the sieve according to Turkish Food Codex, Wheat Flour communique. The hulled rice (paddy) and rice sample were supplied from a local rice producer (milling yield 68\%) in Tosya district of Kastamonu. For preparing of rice flour, the dried rice grains were milled with a laboratory mill (EQM-402 Mixer Mill, Spain) in Kastamonu University Central research laboratory. The mill used was designed for the crushing, and milling of hard or semihard samples. The barley sample which was named "Aydan Hanım", local oat and the rye which were named "Black rye" were supplied from the grains which were harvested in 2017 from Gövdecili village of Yozgat (Turkey), and the samples were milled by the traditional stone mill in a local company (İhsangazi, Kastamonu). Before milling, the grains were hydrated by adding $200 \mathrm{~g}$ of water to $10 \mathrm{~kg}$ of the kernel to make the seed coats less brittle and prevent kernel breakage [13]. The milling processes of barley, oat, and rye performed in the stone mill. The grains were separated from the foreign material (straw and stones) by passing through the selector and then followed the stages of, hydrating/conditioning, grinding (for open the kernel and scrape off the endosperm), sizing and sifting (sieving) respectively. The stone mill made from chiseled emery stone was used in this study.The cleaned grains were fed through a hopper in to between the two plates and ground to flour. The flours were sifted through a 60-mesh sieve.

\section{Physico-chemical properties}

Ash and protein content were determined according to the AACC methods [14]. All the parameters were reported on dry weight basis. The protein content was performed by using Kjeldahl method. The amount of nitrogen determined for the expression of the results was multiplied by 5.70 for wheat, and flour and 5.83 for barley, rye, oats, rice and flour. 
Table 1

Supplying properties of the raw materials

\begin{tabular}{|c|c|c|c|c|}
\hline Sample & Space & $\begin{array}{c}\text { Source } \\
\text { (district/city) }\end{array}$ & Milling technique & Supplier/Miller \\
\hline Wheat & $\begin{array}{c}\text { Ekiz wheat } \\
\text { (Triticum } \\
\text { aestivum) }\end{array}$ & $\begin{array}{l}\text { July } 2017 \\
\text { Devrekani/ } \\
\text { Kastamonu }\end{array}$ & $\begin{array}{c}\text { Modern milling } \\
\text { process } \\
\text { (Cleaning, tempering, } \\
\text { milling, sifting and } \\
\text { separating }\end{array}$ & $\begin{array}{l}\text { Üçbaşak Milling } \\
\text { Factory/ Devrekani/ } \\
\text { Kastamonu }\end{array}$ \\
\hline $\begin{array}{l}\text { Paddy/rice } \\
\text { Rice flour }\end{array}$ & Tosya rice & $\begin{array}{l}\text { August } 2017 \\
\text { Tosya/ } \\
\text { Kastamonu }\end{array}$ & $\begin{array}{l}\text { Modern milling } \\
\text { process (Pre- } \\
\text { cleaning, husking, } \\
\text { paddy seperation, } \\
\text { polishing) } \\
\text { Laboratory mill } \\
\text { (EQM-402) }\end{array}$ & $\begin{array}{c}\text { Atılım Ticaret/ } \\
\text { Tosya/ Kastamonu } \\
\\
\text { Kastamonu } \\
\text { University } \\
\text { Central research } \\
\text { laboratory }\end{array}$ \\
\hline $\begin{array}{l}\text { Oat } \\
\text { Rye }\end{array}$ & $\begin{array}{c}\text { Aydan } \\
\text { hanım } \\
\text { Local } \\
\text { variety } \\
\text { Black Rye } \\
\text { (local } \\
\text { variety) }\end{array}$ & $\begin{array}{l}\text { July } 2017 \\
\text { Gövdecili/ } \\
\text { Yozgat }\end{array}$ & $\begin{array}{c}\text { Traditional stone } \\
\text { miller } \\
\text { (Cleaning, hydrating/ } \\
\text { conditioning, } \\
\text { grinding, sizing and } \\
\text { sifting) }\end{array}$ & $\begin{array}{c}\text { Mergüze Organik } \\
\text { Tarım/ } \\
\text { İhsangazi/ } \\
\text { Kastamonu }\end{array}$ \\
\hline
\end{tabular}

\section{In-vitro mineral (MD) and protein digestibility (PD)}

The sample $(1 \mathrm{~g})$ was incubated with $25 \mathrm{~mL}$ of pepsin solution $(0.03 \mathrm{~N} 1 \mathrm{~L} \mathrm{HCl}+2 \mathrm{~g}$ pepsin) at $37^{\circ} \mathrm{C}$ for $3 \mathrm{~h}$. Each sample was filtered by an ashless filter paper. The pellet and filter paper were burned together in the furnace at $900{ }^{\circ} \mathrm{C}$ and the ash value was calculated. The digestible mineral content was obtained with their differences. The MD value (\%) was obtained [15] by using the following equation:

$$
M D \%=\frac{\text { Digestible Mineral Content }}{\text { Total Mineral Content }} \times 100
$$

The in vitro PD values determined by the method of Rizzello et al. [16]. PD values (\%) were obtained by using the following equation:

$$
P D \%=\frac{N \text { in supernatant }-N \text { in pepsin enzyme }}{N \text { in sample }} \times 100
$$




\section{Phytic acid content}

For determination of phytic acid content, the seed samples were grounded and the phytic acid extraction was carried out by adding $10 \mathrm{~mL}$ of Hydrochloric acid $(0.2 \mathrm{~N})$ to $0.5 \mathrm{~g}$ and placed on the horizontal shaker at room temperature for $24 \mathrm{~h}$. The sodium salt of phytic acid $\left(\mathrm{C}_{6} \mathrm{H}_{6} \mathrm{O}_{24} \mathrm{P}_{6} \mathrm{Na}_{12}\right)$ obtained from Sigma (D216305) was used to preparing the phytate reference solution. The stock solution was prepared $0.15 \mathrm{~g}$ of sodium phytate in $100 \mathrm{ml}$ of distilled water. The reference solution was prepared with diluting the stock solution with $\mathrm{HCl}$ concentration in the range from 3 to $30 \mu \mathrm{g} / \mathrm{ml}$. The phytic acid was analyzed in the protocol as described by Haug and Lantzsch [17].

\section{Mineral content}

The mineral content was measured by using the microwave (Milestone MLS 1200, Italy) nitric acid digestion procedure and it was followed by inductively coupled plasma optical emission spectrometry (ICP-OES) (Spectro Blue, Germany) method. The samples were grinded and then approximately $1 \mathrm{~g}$ of them was weighed directly to PTFE flasks after adding $7 \mathrm{~mL}$ of $\mathrm{HNO}_{3}(67 \% \mathrm{v} / \mathrm{v})$ and $1 \mathrm{~mL} \mathrm{H}_{2} \mathrm{O}_{2}(30 \% \mathrm{v} / \mathrm{v})$ and subjected to following digestion program: the temperature was raised to $170{ }^{\circ} \mathrm{C}(15 \mathrm{~min})$, and waited at $170{ }^{\circ} \mathrm{C}$ for $10 \mathrm{~min}$. After cooling at room temperature, sample solutions were transferred into $50 \mathrm{~mL}$ polyethylene flasks. The digested samples were analyzed by ICP-OES [18].

\section{Statistical analysis}

The data were reported as the average \pm standard deviation. Variance of analysis (ANOVA) (IBM-SPSS 1.0.0.781) by Tukey test $(p<0.05)$ was used for comparison of the results between all samples. $t$-test was used to determine the effects of the application (before and after milling) on the statistical significance level and to compare the varieties of grains among themselves.

\section{Results and discussion}

\section{Physiochemical properties}

The ash contents of the paddy $\left(3.499^{\mathrm{a}}\right)$, oat $\left(2.294^{\mathrm{b}}\right)$ and barley samples were significantly $(p<0.05)$ higher than the other grains, respectively (Table 2$)$. The ash contents of the cereals decreased at various ratios by the debranning and milling processes applied to the wheat, barley, oats, rye, and rice. Especially the ash content seriously reduced in the paddy and wheat via milling process $(p<0.05)$. This case may be attributed to the difference in the bran and hull layer content and consequently in the grain morphology. Furthermore, the amount of ash in the cereals increases from the center of the grain to the outer layers depending on the distribution of the major and trace elements [3]. The paddy is a hulled grain and this layer is removed from the raw grain to reveal whole rice before rice flour production. During the rice milling process, this stage is named as dehusking [19]. The ash content of the dehusked rice was significantly lower $(p<0.05)$ than the other grains. 
Ash and protein contents of the cereal grains and flour samples

\begin{tabular}{|c|c|c|c|c|c|}
\hline Cereal & & $\begin{array}{l}\text { Ash } \\
(\%)\end{array}$ & value* & $\begin{array}{c}\text { Protein } \\
(\%)\end{array}$ & $p$ va \\
\hline \multirow[b]{2}{*}{ Wheat } & in & $261 \pm 0.168^{\mathrm{d}}$ & \multirow[b]{2}{*}{.01} & $.619 \pm 0.339^{\mathrm{a}}$ & \multirow[b]{2}{*}{0.065} \\
\hline & $\mathrm{F}$ & & & & \\
\hline \multirow{2}{*}{ Barley } & $n$ & 0 & & & \multirow{2}{*}{0.329} \\
\hline & Flot & 1.92 & & & \\
\hline \multirow{2}{*}{ Ry } & Grain & 1.37 & \multirow{2}{*}{0.0} & ab & \multirow{2}{*}{0.174} \\
\hline & Flour & $1.292 \pm 0$ & & 10.6 & \\
\hline \multirow[b]{2}{*}{0} & Grain & $2.294 \pm 0.016^{\mathrm{b}}$ & \multirow{2}{*}{0.4} & 9.21 & \multirow[b]{2}{*}{0.0} \\
\hline & Flour & & & & \\
\hline \multirow{2}{*}{ Padc } & Grain & 3.499 & \multirow{2}{*}{0.003} & & \multirow{2}{*}{0.019} \\
\hline & Flour & $0.930 \pm 0.014^{\mathrm{e}}$ & & $5.439 \pm 0.074^{\mathrm{d}}$ & \\
\hline
\end{tabular}

* $(p<0.05)$ means that the values statistically different.

** Different letters in the same column indicate significant differences $(p<0.05)$ between the samples.

In a study conducted by Oghbaei and Prakash [20], which was examined the effect of the milling process to the flour of the physicochemical properties, the ash content of the whole wheat flour was $1.89 \%$, the ash content of the wheat flour obtained as a result of refining was $0.78 \%$. The removing of the germ and bran layers during milling process reduces the ash content of the flour [21-23]. However, the final nutrient content of the wheat will depend on the extent to which the outer bran and aleurone layers are removed during debranning processing, as this is where the fiber and minerals tend to be concentrated.

Barley, oats and rye used in the study were made into flour by grinding in the stone mill. These cereals entered to milling system together with their husk, they were grinded together at the mill. At the end of the milling system, although some part of them removed by the coarse bran sieving system, a little bit of fine bran (especially aleurone layer) could mix to flour during the sifting. At the same time, the morphologically combined structure of the husk and endosperm section of the barley caused the bran layer especially aleurone part to be not completely separated from the endosperm. Therefore, no statistically significant difference $(p>0.05)$ was found in the ash contents of the cereal grains and their flours, especially in barley. This situation reduces the quality of the flour from the technological point of view, but it makes them rich in nutritional quality. The results of the study have shown that mineral content increases depending on bran/husk content of the grains.

The lowest protein content was determined in the paddy $\left(7.917^{\mathrm{c}}\right)$ and rice $\left(5.439^{\mathrm{d}}\right)$ samples and the highest rate was found in wheat $\left(10.619^{\mathrm{a}}\right)$ grain (Table 2$)$. When the raw materials and flour were evaluated together, the amount of protein decreased in wheat and rice flour by milling process, the amount of protein increased in barley, oats and rye flour slightly. But the change between grains and flours was found statistically insignificant except paddy/rice and indicated with the same letters in Table $2.70 \%$ of the cereal proteins found with starch granules in the endosperm, which forms the main structure of cereal flours, are in glycoprotein form. Especially oat proteins exhibit differences in terms of the structural and protein fractions and as different from the other cereals, most of the storage proteins in the oat are found in the endosperm [24]. It can be said that the presence of storage proteins predominantly in the endosperm leads to an increase in the protein content of oat flour after 
separated the bran (Table 2). Therefore, the protein contents of the oat sample were found statistically insignificant $(p>0.05)$ before and after the debranning process. In a study conducted about dephytinization of wheat and rice brans, the ash and protein content of the wheat and rice bran were found as $5.6 \% ; 14.2 \%$ and $9.7 \% ; 16.5 \%$, respectively [10]. According to these results, the rice bran has more ash and protein content than the wheat bran. In the present study similarly, removing the bran layer has been more effective in the rice sample than the wheat sample $\left(p_{\text {rice }}<p_{\text {wheat }}\right)$ (Table 2$)$.

\section{In-vitro digestibility and phytic acid content}

Digestibility rate (\%) and phytic acid content of the samples

Table 3

\begin{tabular}{|c|c|c|c|c|c|c|c|}
\hline \multicolumn{2}{|c|}{ Cereal } & $\begin{array}{c}\text { Mineral } \\
\text { digestibility } \\
(\%)\end{array}$ & $\begin{array}{c}p \\
\text { value* }\end{array}$ & $\begin{array}{c}\text { Protein } \\
\text { digestibility } \\
(\%)\end{array}$ & $\begin{array}{c}p \\
\text { value* }\end{array}$ & $\begin{array}{l}\text { Phytic acid } \\
(\mathrm{mg} / 100 \mathrm{~g})\end{array}$ & $\begin{array}{c}p \\
\text { value* }\end{array}$ \\
\hline \multirow[t]{2}{*}{ Wheat } & Grain & $\begin{array}{l}45.38 \pm \\
3.60^{\mathrm{abc}}\end{array}$ & \multirow[t]{2}{*}{0.073} & $50.66 \pm 3.30^{\mathrm{cd}}$ & \multirow{2}{*}{0.032} & $2471.88 \pm 0.31^{\mathrm{a}}$ & \multirow{2}{*}{0.000} \\
\hline & Flour & $49.61 \pm 0.49^{\mathrm{ab}}$ & & $74.46 \pm 2.19^{\mathrm{ab}}$ & & $1900.50 \pm 0.71^{b c}$ & \\
\hline \multirow[b]{2}{*}{ Barley } & Grain & $40.72 \pm 0.00^{\mathrm{bc}}$ & \multirow[b]{2}{*}{0.097} & $36.49 \pm 0.97^{\mathrm{ef}}$ & \multirow[b]{2}{*}{0.041} & $2328.13 \pm 2.08^{\mathrm{ab}}$ & \multirow[b]{2}{*}{0.000} \\
\hline & Flour & $\begin{array}{l}44.61 \pm \\
0.60^{\mathrm{abc}}\end{array}$ & & $65.19 \pm 2.85^{\mathrm{b}}$ & & $1940.63 \pm 0.66^{b c}$ & \\
\hline \multirow{2}{*}{ Rye } & Grain & $45.70 \pm 0.42^{\mathrm{ab}}$ & \multirow{2}{*}{0.050} & $53.81 \pm 3.19^{c}$ & \multirow{2}{*}{0.055} & $1715.63 \pm 1.10^{\mathrm{c}}$ & \multirow{2}{*}{0.186} \\
\hline & Flour & $58.30 \pm 1.20^{\mathrm{a}}$ & & $66.51 \pm 1.09^{a}$ & & $1709.38 \pm 1.28^{c}$ & \\
\hline \multirow{2}{*}{ Oat } & Grain & $36.24 \pm 2.01^{b c}$ & \multirow{2}{*}{0.067} & $40.54 \pm 0.10^{\mathrm{de}}$ & \multirow{2}{*}{0.036} & $2050.00 \pm 2.74^{\mathrm{abc}}$ & \multirow{2}{*}{0.001} \\
\hline & Flour & $46.44 \pm 1.08^{\mathrm{ab}}$ & & $65.63 \pm 1.41^{\mathrm{b}}$ & & $1818.75 \pm 0.44^{\mathrm{c}}$ & \\
\hline \multirow{2}{*}{$\begin{array}{l}\text { Paddy } \\
\text { (rice) }\end{array}$} & Grain & $30.16 \pm 1.01^{\mathrm{c}}$ & \multirow{2}{*}{0.064} & $48.69 \pm 1.24^{\mathrm{cd}}$ & \multirow{2}{*}{0.016} & $1559.38 \pm 0.22^{\mathrm{c}}$ & \multirow{2}{*}{0.000} \\
\hline & Flour & $58.35 \pm 2.86^{\mathrm{a}}$ & & $66.13 \pm 0.43^{\mathrm{ab}}$ & & $921.87 \pm 0.49^{\mathrm{d}}$ & \\
\hline
\end{tabular}

$*(p<0.05)$ means that the values statistically different.

$* *$ Different letters indicate significant differences $(p<0.05)$ between the samples.

However, this rising was not found statistically significant $(p>0.05)$ except for the rye sample $(p \leq 0.05)$. While the sample which had the highest MD rate was the rice $\left(58.35^{\mathrm{a}}\right)$, the lowest one was the paddy $\left(30.16^{c}\right)$. This was related to the high amount of ash content of the paddy hull which was completely separated from the grain, and to the low rate of phytic acid content in the rice. This case was supported by the decreased total phosphorus $(\mathrm{P})$ content of the rice flour after dehulling and milling in Table 4. As shown in Table 3 the rice flour is the sample that has the lowest phytic acid content and one of the samples which has the highest PD rate. It has been found that the milling process resulted in a greater increase in PD compared to the MD of the cereal grains. It was determined that the milling process applied to cereals caused an increase in PD in all flour samples compared to grain (Table 3). The highest increase $(p<0.05)$ was detected in paddy. The flour which had the highest protein digestibility was the wheat flour. Except for rye $(p>0.05)$ the increase in other cereals was found statistically significant $(p<0.05)$. It is known that the antinutrients such as phytic acid reduces mineral bioavailability and protein absorption of foods thanks to their chelating properties. They causes to micronutrient malnutrition and mineral deficiencies. (11). 
In the present study, the highest phytic acid content was found $2471.88 \mathrm{mg} / 100 \mathrm{~g}$ in the wheat sample. This result supported the view that wheat and bran were rich sources of phytic acid. It was stated that phytic acid was found mostly in the outer layers of the wheat grain, and that different wheat fractions obtained by milling process had different phytic acid content [25]. Moreover, it was indicated that the bran of wheat and rice contains a considerable amount of phytic acid (myo-inositol hexaphosphate) which acts as an antinutrient substance [10]. Fulcher and Duke [26] reported that most of the phytic acid phosphorous (87\%) that caused the limitation of digestibility was present mostly in aloeoron layer. Gupta et al. [27], also reported that the antinutrients such as phytic acid were also removed by debranning of the bran layer from the cereal grains during milling. In this study, the phytic acid content of the cereal grains decreased in the milling process. Except for rye $(p>0.05)$, the decrease other cereals were found statistically significant $(p<0.05)$. The milling process is not a process that activates the phytase enzyme that breaks down phytic acid. However, the debrannig/dehulling process is a common method to removing of phytic acid from cereals. Despite its change according to grain varieties, the bran and husk layers of the grain generally contain high phytic acid.

Table 3 shows the untreated cereal grains have a high content of phytic acid due to their bran and hull layer. However, it is seen that the amount of phytic acid decreases in the flour samples due to the removing of bran and hull layers via the milling process. Especially rice, wheat, and barley were provided in serious decline. This case may be attributed to the process of debranning/dehusking process of the wheat and paddy samples during milling. The situation in the other grains was caused by milling of the stone mill and subsequent sieving.

\section{Minerals content in cereals}

When the mineral contents of the grains and flours used in the study were evaluated together, the highest minerals in the cereals were determined as $\mathrm{K}, \mathrm{P}, \mathrm{Mg}, \mathrm{Ca}$ and $\mathrm{Na}$, respectively (Table 4). The grain with the highest $\mathrm{K}$ and $\mathrm{Ca}$ content was oats; with the highest $\mathrm{P}$ and $\mathrm{Na}$ content was barley; the grain with the highest $\mathrm{Mg}$ content was paddy. In a study, it was stated that oats were a bit richer than barley in terms of some minerals [1]. In this study, the oat sample was found richer than other grain samples in terms of " $\mathrm{Ca}, \mathrm{K}, \mathrm{Fe}, \mathrm{Ba}, \mathrm{Al}$ content, was found to be equal in terms of Se amount. Although $\mathrm{Al}, \mathrm{Fe}, \mathrm{Zn}, \mathrm{Ba}$ and Se were low in cereals, paddy sample due to the owned husk layer had very high values in terms of $\mathrm{Al}$ and $\mathrm{Fe}$ content compared to other grains. Although the wheat has high daily intake in the human diet, it contains insufficient level Fe and Zn.In a study conducted by Welch and Graham [28], it was indicated that the wheat had inadequately Zn content inherently.

Phosphorus $(\mathrm{P})$ is an important element obtain growth and maturation of grain in many cereals. $80 \%$ of the phosphorus is the phytate phosphorus which is located in the bran (aleurone) layer. The amount of phosphorus increases with the growth of the cereal grain [29]. $p$ level of the samples decreased due to the removal of the bran/husk by the peeling, polishing and grinding processes applied to the grains. Because a significant part of the bran layer was separated, the phosphorus level was significantly reduced after milling, especially in wheat $(p=0.004)$ and paddy $(p=0.000)$. 
Mineral content (ppm) of the cereal grain and flour samples

\begin{tabular}{|c|c|c|c|c|c|c|c|c|c|c|c|}
\hline \multicolumn{12}{|c|}{ Minerals } \\
\hline & Milling & $\mathbf{N a}$ & $\mathbf{C a}$ & $\mathbf{K}$ & $\mathrm{Mg}$ & $\mathbf{Z n}$ & $\mathbf{F e}$ & Se & Ba & Al & $\mathbf{P}$ \\
\hline \multirow{4}{*}{ Wheat } & & 62.40 & 356.50 & 3528.70 & 765.10 & 11.30 & 11.90 & 2.90 & 3.01 & 14.00 & 1772.50 \\
\hline & $(\mathrm{p}$ & \pm 0.6 & \pm 3.3 & \pm 17.7 & \pm 2.90 & \pm 0.10 & \pm 0.10 & \pm 0.00 & \pm 0.01 & \pm 0.03 & \pm 13.60 \\
\hline & After & 24.20 & 253.90 & 1772.00 & 251.80 & 1.50 & 2.60 & 3.20 & 1.28 & & 826.20 \\
\hline & & \pm & \pm 2.60 & +3 & \pm 2 & \pm 0.10 & \pm 0.10 & \pm 0.00 & \pm 0.02 & \pm 0.13 & \pm 6.10 \\
\hline \multicolumn{2}{|c|}{$p^{*}$ value } & 0.001 & \begin{tabular}{|l|}
0.001 \\
\end{tabular} & 0.001 & \begin{tabular}{|l|}
0.001 \\
\end{tabular} & 0.006 & 0.003 & 0.000 & 0.007 & 0.013 & 0.004 \\
\hline \multirow{4}{*}{ Barley } & Before & 157.80 & 325.70 & 4393.10 & 786.50 & 12.70 & 7.10 & 2.70 & 0.88 & 4.24 & 1819.50 \\
\hline & (nnm) & \pm 1.00 & \pm 3.50 & \pm 18.50 & \pm 1.70 & \pm 0.00 & \pm 0.00 & \pm 0.00 & \pm 0.00 & \pm 0.02 & \pm 4.60 \\
\hline & After & 84.90 & 279.00 & 4347.70 & 834.30 & 14.0 & 14.0 & 3.10 & 1.62 & 15.41 & 1997.70 \\
\hline & & \pm 0.50 & \pm 4.30 & \pm 22.90 & \pm 2.90 & \pm 0.20 & \pm 0.10 & \pm 0.10 & \pm 0.01 & \pm 0.04 & \pm 7.80 \\
\hline$p^{*}$ & value & \begin{tabular}{|l|}
0.001 \\
\end{tabular} & 0.045 & 0.041 & \begin{tabular}{|l|}
0.039 \\
\end{tabular} & 0.097 & 0.009 & 0.156 & 0.009 & 0.001 & 0.028 \\
\hline \multirow{4}{*}{ Rye } & Before & 13.90 & 251.70 & 4436.00 & 707.10 & 9.50 & 3.30 & 2.90 & 2.36 & 2.93 & 9.30 \\
\hline & $(1$ & \pm 0.30 & \pm 2.70 & +3 & \pm 2.90 & \pm 0.10 & \pm 0.10 & \pm 0.20 & \pm 0.01 & \pm 0.01 & 40 \\
\hline & After & 26.30 & 374.00 & 4480.00 & 764.70 & 14.40 & 32.70 & 3.30 & 3.09 & 47.93 & 1722.90 \\
\hline & & \pm 0.50 & \pm 5.20 & \pm 5.80 & \pm 4.90 & \pm 0.20 & \pm 0.30 & \pm 0.10 & \pm 0.01 & \pm 0.34 & \pm 2.90 \\
\hline$p^{*}$ & value & 0.026 & 0.027 & 0.083 & 0.054 & 0.026 & 0.006 & 0.156 & 0.009 & 0.000 & 0.016 \\
\hline \multirow{4}{*}{ Oat } & Before & 21.40 & 532.70 & 4664.60 & 734.80 & 7.90 & 24.50 & 2.50 & 6.41 & 6.90 & 11 \\
\hline & & \pm 0.20 & & & & & \pm 0.10 & \pm 0.20 & \pm 0.07 & & \\
\hline & After & 46.90 & 497.90 & 4534.00 & 754.50 & 10.00 & 26.00 & 3.20 & 5.31 & 29.06 & 1369.10 \\
\hline & & \pm 0.50 & \pm 2.50 & \pm 14.80 & \pm 1.00 & \pm 0.00 & \pm 0.20 & \pm 0.10 & \pm 0.01 & \pm 0.07 & \pm 2.80 \\
\hline$p^{*}$ & value & 0.000 & 0.046 & 0.072 & 0.032 & 0.006 & 0.084 & 0.090 & 0.006 & 0.000 & 0.010 \\
\hline \multirow{4}{*}{ Paddy } & Before & 48.70 & 355.10 & 4243.60 & 903.90 & 6.10 & 139.60 & 3.50 & 1.29 & 172.28 & 1687.80 \\
\hline & & \pm 0.20 & & & \pm 2.50 & \pm 0.10 & \pm 1.30 & \pm 0.10 & \pm 0.04 & & \pm 2.50 \\
\hline & After & 5.90 & 20.50 & 1232.40 & 224.10 & 2.70 & & 2.40 & 0.07 & 1.87 & 651.40 \\
\hline & & & & & & & nd & & \pm 0.00 & & \pm 4.60 \\
\hline \multicolumn{2}{|c|}{$p^{*}$ value } & 0.000 & 0.000 & 0.000 & \begin{tabular}{|l|}
0.000 \\
\end{tabular} & 0.002 & 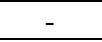 & 0.006 & 0.000 & 0.000 & 0.000 \\
\hline
\end{tabular}

$*(p<0.05)$ means that the values statistically different.

In the study, the decrease in the level of all minerals as a result of milling of paddy and wheat grain was evaluated statistically significant $(p<0.05)$. However, the decreases in mineral contents were at different levels, this decrease could be due to the distribution of minerals in the different layers and in the fractions of the wheat. From the outside to the inside, the wheat bran comprises the pericarp, the intermediate layers (the seed coat, the nucellar epidermis), and the aleurone layer. The removing the outer layers of the wheat grain towards to aleurone layer leads to a significant decrease in the amount of some minerals. In a study investigated to effects of different degree of pearling treatment onto concentrations of different elements, it was reported that as the pearling degree increased, the rates of $\mathrm{K}$, $\mathrm{Mg}, \mathrm{Fe}$, and $\mathrm{Zn}$ decreased. Because the aleurone layer is especially rich in terms of $\mathrm{K}, \mathrm{P}, \mathrm{Mg}$, $\mathrm{Zn}$, and $\mathrm{Cu}$ elements compared to other wheat layers [4]. In a study conducted by Lorenz et al. [30], as the amount of ash in wheat increased, the amount of $\mathrm{Fe}$ and $\mathrm{Zn}$ increased relatively, but the same relationship was not observed in the $\mathrm{Ca}$. The amount of $\mathrm{K}, \mathrm{Mg}, \mathrm{Cu}$, $\mathrm{Zn}$, and Fe minerals increased as the milling yield of the wheat increased and there was no change in $\mathrm{Ca}$ mineral level in accordance with the data reported by Ekinci and Unal [31]. It was associated with the different distribution of $\mathrm{Ca}$ in wheat grain by them. 
The opposite results were obtained for the content of the Fe and $\mathrm{Zn}$ of barley, oat and rye, their rate increased with the milling process. In agreement with earlier findings [4, 32], it can be evaluated as that $\mathrm{Zn}$ and $\mathrm{Fe}$ are more evenly distributed in these grains.

The rye flour had the highest $\mathrm{Zn}(14.40 \mathrm{ppm})$ and $\mathrm{Fe}$ (32.70 ppm) content compared to the other samples. It was stated that in a study conducted by Kutman et al. [33], the nitrogen application to soil affected $\mathrm{Fe}$ and $\mathrm{Zn}$ concentrations in the whole grain $(50 \%)$ and endosperm (80\%) significantly. It was found also a close relationship between $\mathrm{Zn}$ and protein in biological systems and that $\mathrm{Zn}$ required protein to form structural integrity in the grain [34,35]. Moreover, Ekinci and Unal [30] reported that there was a positive correlation between the amount of protein in the flours and the amount of $\mathrm{K}$ and $\mathrm{Mg}$. These findings specify that there is a positive relationship between the protein content and accumulation of some minerals to plant and also their concentration. In this study, it was determined that rye flour contained the highest rates of $\mathrm{Zn}$ and $\mathrm{Fe}$ and the highest protein content. Furthermore, by milling rye flour, there was provided an increase in the amount of $\mathrm{Mg}$ and $\mathrm{K}$, together with increasing protein. Weaver et al. [36] stated that some minerals increased due to the removal of the outer layer by grinding of oat. As the similar finding was observed in oat sample. The amounts of $\mathrm{Na}, \mathrm{Mg}, \mathrm{Zn}, \mathrm{Fe}, \mathrm{Se}, \mathrm{Al}, \mathrm{Ba}$, and $\mathrm{P}$ increased with the milling.

Selenium concentrations in the barley, oat and rye were not influenced by the milling process statistically $(p>0.05)$. Although the changing of its' level was found statistically significant in wheat and rice samples, it's concentration exhibited less change relatively compared to other minerals. In a study, it was reported that Se was located to be uniform throughout the aleurone layer and the protein matrix which surrounded the starch granules in wheat endosperm [37]. Moreover, it was stated similar to our findings that Selenium was the only mineral distributed almost homogeneously in all grain types and fractions of the grain [4].

\section{Conclusion}

The result of the study has shown that the level of the minerals changed depending on the bran/hull content of the grains. Whereas the bran and ash contents were decreased by dehulling/debranning process, the mineral rates were differently affected. Although the low bran and ash content is desirable with respect to regulations and technological usage, the low level of mineral content means undesirable nutritional quality for the cereal products. The rate of some minerals increased due to their distribution and location in the grain layer. Moreover, the mineral composition in cereals was also affected by the type of grain. The dehulling/debranning process generally increased the digestibility rates and decreased phytic acid content significantly. Because the different treatments such as soaking, fermentation or cooking process increased the digestibility and decreased the phytic acid level via they activate the phytase enzyme, the effects of the combination of the debranning/dehulling treatments with these processes should be researched for improving the nutritional quality of cereal products. It can be suggested that performing technologically appropriate level debranning/dehulling process, and combination with some process such as soaking, fermentation which affected digestibility and dephytinization.

Acknowledgements. This research has been supported by Kastamonu University Scientific Research Projects Coordination Department (Project Number: KÜ-BAP01/2017-56). The authors would like to thank Kastamonu University SRP Coordination Department for their support. 


\section{References}

1. Hübner F., O’Neil T., Cashman K.D., Arendt E.K. (2010), The influence of germination conditions on beta-glucan, dietary fibre and phytate during the germination of oats and barley, European Food Research and Technology, 231, pp. 27-35.

2. Mayer J.E., Pfeiffer W.H., Beyer P. (2008), Biofortified crops to alleviate micronutrient malnutrition, Current Opinion in Plant Biology, 11, pp. 166-170.

3. Delcour J.A., Hoseney R.C. (2010), Principles of cereal science and technology, Chapter 2: Starch., AACC International Inc., pp. 23-51.

4. Brier N., Gomand S.V., Donner E., Paterson D., Delcour J.A., Lombi E. (2015), Smolders E., Distribution of minerals in wheat grains (Triticum aestivum L.) and in roller milling fractions affected by pearling, Journal of Agricultural Food Chemistry, 63(4), pp. 1276-1285.

5. MacMasters M.M., Bradbury D., Hinton J.J.C. (1964), Microscopic structure and composition of the wheat kernel. In I. Hlynka (Ed.), Wheat: Chemistry and technology, American Association of Cereal Chemists, 55-110.

6. Zanoletti, M. Parizad P.A., Lavelli V., Cecchini C., Menesatti P., Marti A., Pagani M.A. (2017), Debranning of purple wheat: recovery of anthocyanin-rich fractions and their use in pasta production, LWT-Food Science and Technology, 75, pp. 663-669.

7. Fjell K.M., Seibel W., Gerstenkorn P. (1996), Method for ash determination by conductivity, Cereal Chemistry, 73, pp. 510-511.

8. Ciccoritti R., Taddei F., Nicoletti I., Gazza L., Corradini D., D’Egidio M.G., Martini D. (2017), Use of bran fractions and debranned kernels for the development of pasta with high nutritional and healthy potential, Food Chemistry, 225, pp. 77-86.

9. Akhter S., Saeed A., Irfan M., Malik K.A. (2012), In vitro dephytinization and bioavailability of essential minerals in several wheat varieties, Journal of Cereal Science, 56(3), pp. 741-746.

10. Özkaya H., Özkaya B., Duman B., Turksoy S. (2017), Effect of dephytinization by fermentation and hydrothermal autoclaving treatments on the antioxidant activity, dietary fiber, and phenolic content of oat bran, Journal of Agricultural and Food Chemistry, 65, pp. 5713-5719.

11. Hendek Ertop, M., Bektaş, M. (2018). Enhancement of bioavailable micronutrients and reduction of antinutrients in foods with some processes, Journal of Food and Health Science, 4(3), pp. 159165.

12. Pomeranz Y. (1988), Wheat Chemistry and Technology, American Association of Cereal Chemists.

13. Bottega G., Caramanico R., Lucisano M., Mariotti M., Franzetti L., Pagani M.A. (2009), The debranning of common wheat (Triticum aestivum L.) with innovative abrasive rolls, Journal of Food Engineering, 94, pp. 75-82.

14. AACC (2000), Approved methods of the American Association of Cereal Chemists, Tenth ed. St. Paul.

15. Hayta M., Hendek Ertop M. (2017), Optimization of sourdough bread incorporation into wheat bread by response surface methodology: bioactive and nutritional properties, International Journal of Food Science and Technology, 52(8), pp. 1828-1835.

16. Rizzello C.G., Curiel J.A., Nionelli L., Vincentini O., Cagno R.D., Silano M., Gobbetti M., Coda R. (2014), Use of fungal proteases and selected sourdough lactic acid bacteria for making wheat bread with an intermediate content of gluten, Food Microbiology, 37, pp. 59-68.

17. Haug W., Lantzsch H.J. (1983), Sensitive method for the rapid determination of phytic acid in cereals and cereal products, Journal of the Science of Food and Agriculture, 34, pp. 1423-1426.

18. Al Khalifa A.S., Ahmad D. (2010), Determination of key elements by ICP-OES in commercially available infant formulae and baby foods in Saudi Arabia, African Journal of Food Science, 4(7), pp. 464-468.

19. Payman S.H., Bagheri I., Zareiforoush H. (2014), Milling characteristics of rice grains as affected by paddy mixture ratio and moisture content, International Journal of Biosciences, 4(2), pp. 8797.

20. Oghbaei M., Prakash J. (2013), Effect of fractional milling of wheat on nutritional quality of milled fractions, Trends in Carbohydrate Research, 5, pp. 53-58. 
21. Evers A.D., Kelkens M., McMaster G. (2002), Image analysis of flour for QC and premium product development. In: Proceedings of the international bread baking conference, September, Valencia.

22. Gys W., Gebruers K., Sørensen J.F., Courtin C.M., Delcour J.A. (2004), Debranning of wheat prior to milling reduces xylanase but not xylanase inhibitor activities in wholemeal and flour, Journal of Cereal Science, 39, pp. 363-369.

23. Cordain L., Eaton S.B., Sebastian A., Mann N., Lindeberg S., Watkins B.A., et al. (2005), Origins and evolution of the western diet: health implications for the $21^{\text {st }}$ century, American Journal of Clinical Nutrition, 81, pp. 341-354.

24. Klose C., Schehl B.D., Arendt E.K. (2009), Fundamental study on protein changes taking place during malting of oats, Journal of Cereal Science, 49, pp. 83-91.

25. Camire A.L., Clydesdale F.M., (1982), Analysis of phytic acid in foods by HPLC, Journal of Food Science, 47, pp. 575-578.

26. Fulcher R.G., Duke T.K.R. (2002), Whole-Grain Structure and Organization, Implications for Nutritionists and Processors, Page 9 in Whole-Grain Foods in Health and Disease, I. Marquart, J. Slavin, and R.G. Fulcher, eds. AACC Intl., St. Paul, MN, U.S.A.

27. Gupta R.K., Gangoliya S.S., Singh N.K. (2015), Reduction of phytic acid and enhancement of bioavailable micronutrients in food grains, Journal Food Science and Technology, 52(2), pp. 676684

28. Welch, R.M. Graham R.D. (2004), Breeding for micronutrients in staple food crops from a human nutrition perspective, Journal of Experimental Botany, 55(396), pp. 353-364.

29. Vats P., Banerjee U.C. (2004), Production studies and catalytic properties of phytases (myoinositol-hexakis-phosphate phosphohydrolases): an overview, Enzyme and Microbial Technology, 35, pp. 3-14.

30. Lorenz K., Loewe R., Weadon D., Wolf W. (1980), Natural levels on nutrients in commercially milled flours, II. mineral analyses, Cereal Chemistry, 57, pp. 65-69.

31. Ekinci R., Ünal S. (2002), Mineral contents of various flour types produced in different region of Türkiye, Pamukkale University. Journal of Engineering Science, 8, pp. 91-96.

32. Lombi E., Hettiarachchi G.M., Schecke K.G. (2011), Advanced in situ spectroscopic techniques and their applications in environmental biogeochemistry: introduction to the special section, $J$. Environ. Qual., 40, pp. 659-666.

33. Kutman U.B., Yıldız B., Çakmak İ. (2011), Improved nitrogen status enhances zinc and iron concentrations both in the whole grain and the endosperm fraction of wheat, Journal of Cereal Science,53(1), pp. 118-125.

34. Morgounov A., Gomez-Becerra H.F., Abugalieva A., Dzhunusova M., Yessimbekova M., Muminjanov H., Zelenskiy Y., Öztürk L., Çakmak İ. (2007), Iron and zinc grain density in common wheat grown in Central Asia, Euphytica., 155(1-2), pp. 193-203.

35. Peleg Z., Saranga Y., Yazıcı A., Fahima T., Öztürk L., Çakmak İ. (2008), Grain zinc, iron and protein concentrations and zinc-efficiency in wild emmer wheat under contrasting irrigation regimes, Plant Soil, 306(1-2), pp. 57-67.

36. Weaver, C.M., Chen, P.H., Rynearson, S.L. (1981), Effect of milling on trace- element and protein content of oats and barley, Cereal Chemistry, 58, pp. 120-124.

37. Moore K.L., Schröder M., Lombi E., Zhao F.J., McGrath S.P., Hawkesford M.J., Shewry P.R., Grovenor C.R.M. (2010), NanoSIMS analysis of arsenic and selenium in cereal grain, New Phytologist, 185, pp. 434-445. 